\title{
SANKSI ADMINISTRATIF DENDA PENDEKATAN LAPORAN KEUANGAN ATAS PELANGGARAN PERSAINGAN USAHA TIDAK SEHAT ${ }^{1}$
}

\author{
Suwinto Johan \\ Fakultas Bisnis, Universitas Presiden \\ Jababeka Education Park, Jl. Ki Hajar Dewantara, Kota Jababeka, Cikarang Baru, Bekasi 17550 \\ suwintojohan@gmail.com
}

\begin{abstract}
The imposition of fines for monopolistic practices and violations of unfair business competition has been regulated in the Job Creation Law (UU CK). The imposition of fines on business actors based on the value of sales. This study aims to discuss the effectiveness of the approach to imposing fines based on financial reports in accordance with the Regulations of the Business Competition Supervisory Commission (KPPU). This study uses qualitative research methods with normative legal. This study conducted a review of the literature and applicable norms. This study concludes that the fines imposed based on the accounting approach to financial statements have technical obstacles in their implementation. Administrative sanctions in the form of fines will not harm business actors. Fines are imposed on a portion of the profits made in the Relevant Market. Entrepreneurs still make a profit. Sanctions or fines cannot be imposed on all violations of the prohibition against monopolistic practices.
\end{abstract}

Keywords: Business Competition Violation; Financial statements; Fines.

\begin{abstract}
Abstrak
Pengenaan sanksi denda terhadap praktik monopoli dan pelanggaran persaingan usaha tidak sehat telah diatur dalam Undang Undang Cipta Kerja (UU CK). Pengenaan denda kepada pelaku usaha berdasarkan nilai penjualan. Penelitian ini bertujuan untuk membahas mengenai efektivitas pendekatan pengenaan denda berdasarkan laporan keuangan sesuai dengan Peraturan Komisi Pengawas Persaingan Usaha (KPPU). Penelitian ini mempergunakan metode penelitian kualitatif dengan legal normatif. Penelitian ini melakukan telaah literature dan norma-norma yang berlaku. Penelitian ini menyimpulkan bahwa denda yang dikenakan berdasarkan pendekatan laporan keuangan secara akuntasi memiliki hambatan teknis dalam pelaksanaanya. Sanksi administratif berupa denda tidak akan membuat pelaku usaha dirugikan. Denda dikenakan pada sebagian keuntungan yang diperoleh pada Pasar Bersangkutan. Pelaku usaha tetap memperoleh keuntungan. Sanksi atau denda tidak dapat dikenakan pada semua pelanggaran larangan praktik monopoli.
\end{abstract}

Kata Kunci: Pelanggaran Persaingan Usaha; Laporan Keuangan; Sanksi Denda.

\footnotetext{
${ }^{1}$ Artikel hasil penelitian mandiri pada tahun 2021.
} 


\section{A. Pendahuluan}

Salah satu latar belakang, adanya Undang Undang Anti Monopoli adalah perjanjian antara Pemerintah Republik Indonesia dengan International Monetary Fund (IMF) setelah krisis moneter melanda Indonesia pada tahun 1998 (Rumatiga, 2021). Pelanggaran terhadap persaingan usaha telah terjadi di Indonesia. Keterlambatan notifikasi pengambilalihan, diskriminasi harga, posisi dominan dan lainnya telah menjadi pelanggaran persaingan usaha di Indonesia (Johan, 2020). Pelanggaran tidak hanya terjadi di Indonesia tetap juga terjadi berbagai negara.

Pelaku usaha memiliki tujuan untuk memperoleh keuntungan sebesar-besarnya. Untuk memperoleh keuntungan, pelaku usaha perlu mengembangkan usahanya. Salah satu bentuk pengembangan usaha adalah melalui pembentukan aliansi. Aliansi antar perusahaan akan mampu menciptakan nilai tambahan pada perusahaan peserta aliansi (Johan, 2011). Dengan aliansi, maka kelompok perusahaan akan menciptakan hambatan masuk kepada perusahaan pesaing lain yang berada di luar kelompoknya.

Berdasarkan penelitian, lembaga jasa keuangan yang terintegrasi dengan induk memiliki kinerja yang lebih efisien, memiliki profitabilitas yang lebih baik, ukuran yang lebih besar dan memiliki pertumbuhan yang lebih baik dibandingkan dengan lembaga keuangan yang tidak memiliki integrasi atau independent (Johan, 2012). Integrasi lembaga jasa keuangan ini meningkatan nilai tambah kompetisi industri. Akan tetapi peningkatan ini akan menghambatnya perusahaan lain ke dalam industri. Perusahaan aliansi akan memiliki posisi dominan. Posisi dominan dapat merugikan masyarakat konsumen. Kelompok usaha terintegrasi akan mampu menentukan harga yang mungkin dapat merugikan konsumen luas atau masyarakat.

Dalam industri penerbangan telah terjadi praktik diskriminasi. Praktik diskriminasi dengan membuat alinasi antar kelompok perusahaan tertentu. Komite Pengawas Persaingan Usaha (KPPU) mengenakan denda kepada Lion Air atas praktik diskriminasi terkait dengan kerja sama penjualan kapasitas kargo. Hal ini telah menutup akses pengiriman barang bagi agen kargo lain selain PT. Lion Express. Hal ini melanggar Pasal 19 (d) Undang-Undang Nomor 5 Tahun 1999 tentang Larangan Praktik Monopoli dan Persaingan Usaha Tidak Sehat (UU LPM). KPPU memberikan sanksi sebesar Rp. 1 Milliar (Sandi, 2021).

KPPU juga mengenakan denda sebesar Rp. 1 Milliar atas praktik diskriminasi terkait dengan pemilihan mitra penjualan tiket umrah oleh Garuda. Garuda melakukan diskriminasi harga pada agen-agen tertentu. Hal ini melanggar Pasal 19 (d) UU LPM (Jelita, 2021).

Selain persaingan usaha, KPPU juga menjatuhkan sanksi atas keterlambatan notifikasi pengambilalihan perusahaan. KPPU mengenakan sanksi denda kepada Gojek Indonesia sebesar Rp. 3,3 Milliar atas keterlambatan pemberitahuan akuisisi terhadap PT. Global Loket Sejahtera (Loket). Hal ini melanggar Pasal 29 UU LPM dan Peraturan Pemerintah (PP) No. 57 Tahun 2010 (Deny, 2021). KPPU memberikan hukuman kepada PT. Saratoga Investama Sedaya sebesar Rp. 1 Milliar karena keterlambatan notifikasi atas pengambilalihan saham PT. Wana Bhakti Sukses Mineral (Susanto, 2021).

Pelanggaran persaingan usaha juga terjadi di berbagai negara. Pemerintah China menjatuhkan denda USD 2,8 Milliar atas praktik anti perrsaingan usaha untuk posisi dominan. Hal ini sejalan dengan kebijakan penegakan anti-monopoli (Bimo, 2021). Lembaga pengawas persaingan usaha di Singapura mengenakan denda pada Grab and Uber atas merger kedua perusahaan trasnportasi online. Penggabungan ini mengakibatkan berkurangnya kompetisi pada pasarl aplikasi ride-hailing (Farras, 2018).

Berdasarkan Undang Undang Nomor 11 Tahun 2020 tentang Cipta Kerja (UU CK) menghapus sanksi denda maksimal. Batasan denda diatur pada Peraturan Pemerintah. UU LPM mengatur batas denda maksimal sebesar Rp. 25 milliar (Rosan, 2021).

Penentuan landasan dan besaran sanksi berupa denda menjadi hal belum jelas. Pelanggaran yang atas pasal sama dapat dikenakan denda yang berbeda. Banyak pertimbangan yang menjadi 
landasan pemberian sanksi denda. Pemerintah mencari pendekatan terbaik dalam perhitungan denda ini.

Penelitian membahas mengenai landasan pengenaan denda berdasarkan UU CK, Peraturan Pemerintah Nomor 44 Tahun 2021 tentang Pelaksanaan Larangan Praktik Monopoli dan Persaingan Usaha Tidak Sehat (PP LPM) dan Peraturan KPPU Nomor 2 Tahun 2021 tentang Pedoman Pengenaan Sanksi Denda Pelanggaran Praktik Monopoli dan Persaingan Usaha Tidak Sehat (PKPPU LPM). Penelitian mengenai hal-hal tersebut masih sangat sedikit. Peraturanperaturan baru diterbikan pada tahun 2021. Keunikan lainnya adalah pembahasan landasan pengenaan sanksi berdasarkan perhitungan laporan keuangan perusahaan pelanggar.

Selain individu perusahaan, sebuah konsorsium dapat dijadikan terlapor dalam pelanggaran persaingan usaha tidak sehat. Sanksi pidana berupa denda dan pidana kurungan pengganti denda dapat dikenakan (Pradhana, W. A., 2020). Perjanjian konsorsium dapat dalam bentuk kartel. Kartel digolongkan sebagai kejahatan dalam persaingan usaha (Nindriani \& Pujiyono, 2020). Pada masa pandemi Covid-19, KPPU melakukan analisis struktur pasar test terhadap pasien Covid-19. KPPU menduga adanya perjanjian tertutup antara rumah sakit pada layanan test covid-19 (Abidin, 2021).

Salah satu amanat UU LPM, KPPU memiliki wewenang dalam menjatuhkan sanksi pidana terhadap korporasi atas pelanggaran UU LPM (Arih, 2020). KPPU memiliki otoritas dalam pemberian sanksi hukum terhadap pelaku yang melakukan praktik monopoli dan persaingan usaha tidak sehat (Kasenda, Q. E., Pangkerego, O. A., \& Sarapun, 2021). KPPU juga dapat memberikan sanksi daftar hitam sebaga sanksi administrative (Made, 2021). Sebelum KPPU menjatuhkan sanksi. KPPU melakukan penyelidikan dan pemeriksaaan termasuk memanggil pelaku usaha, saksi dan saksi ahli serta meminta bantuan penyidkan hingga memutuskan dan menetapkan ada atau tidaknya pelanggaran sesuai dengan ketentuan UU LPM (Paparang, 2019).

KPPU juga dapat menjatuhkan sanksi terhadap penggabungan dan peleburan perusahaan. Sanksi yang dapat diberikan oleh KPPU berupa sanksi aministratif dan/atau pembatalan transaksi penggabungan atau peleburan berdasarkan Pasal 47 UU LPM (Chusna, 2021). Pada transaksi jenis, pelaporan dilakukan secara post-notification. Pelaporan post notification dapat menimbulkan beberapa efek ketidakpastian dan biaya transaksi yang tinggi (Johan, 2020). Pelaporan pengambilalihan juga wajib dilakukan oleh perusahaan asing yang memiliki anak perusahaan di Indonesia (Nazhifah, N. A., Yumarni, A., \& Gilalo, 2019).

Gugatan ganti rugi berkelompok (class action) oleh konsumen terhadap sebuah perusahaan atau sekelompok perusahaan atas pelanggaran persaingan usaha tidak sehat dapat dilakukan. Landasan gugatan ganti rugi ini dapat mempergunakan putusan KPPU. Dalam keputusan KPPU perlu mencamtunkan adanya kerugian masyarakat (Sukarmi, 2021).

Penelitian memiliki pertanyaan penelitian mengenai seberapa efektifkah landasan pengenaan sanksi berdasarkan laporan keuangan berdasarkan PP LPM dan PKPPU LPM? Apakah pengenaan sanksi berdasarkan laporan keuangan dapat dikenakan pada semua pelanggaran larangan praktik monopoli berdasarkan UU LPM? Apakah sanksi denda seimbang dengan keuntungan yang diperoleh pelaku usaha? Pertanyaan-pertanyaan penelitian ini digambarkan pada Gambar 1. 


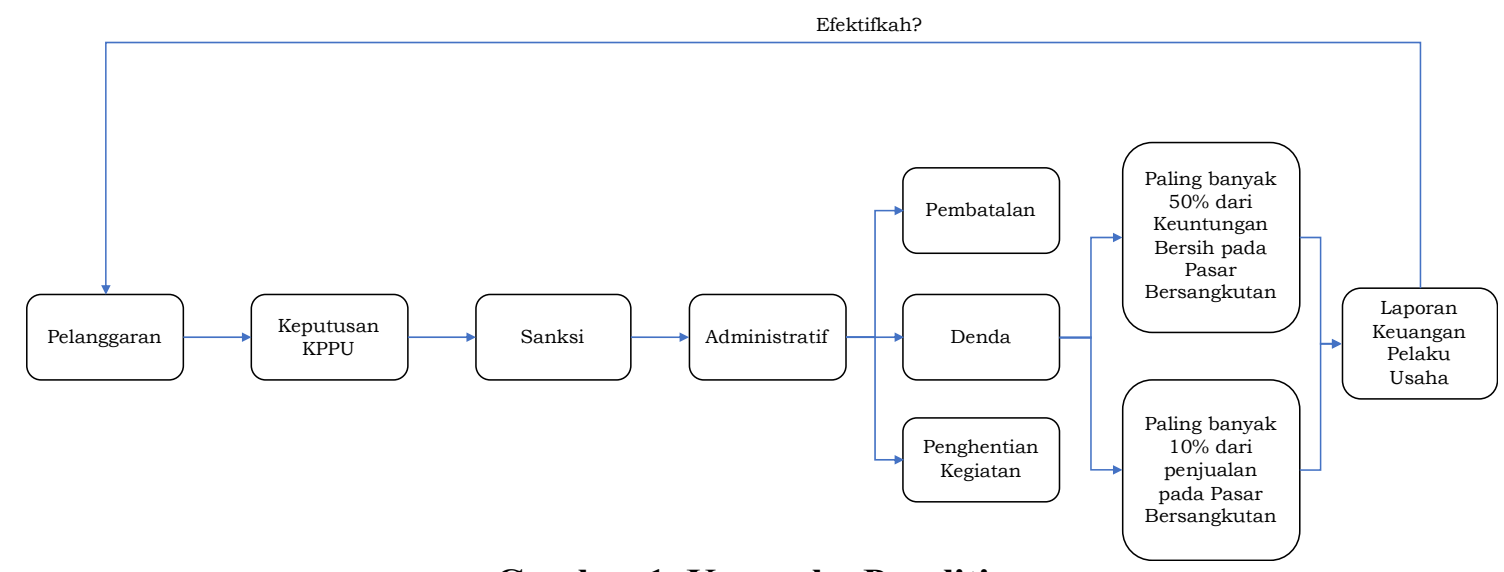

Gambar 1. Kerangka Penelitian

Sumber: hasil penelitian

\section{B. Metode Penelitian}

Penelitian ini mempergunakan metode penelitian hukum judisial normatif atau metode hukum kepustakaan. Adapun landasan penggunaan metode ini berdasarkan latar belakang dan pertanyaan-pertanyaan penelitian. Metode judisial normatif meneliti terhadap bahan-bahan kepustakaan atau bahan penelitian sekunder. Penelitian hukum kepustakaan atau normatif meliputi penelitian terhadap norma-norma hukum dan asas-asas hukum, penelitian juga dilakukan terhadap sistematika hukum, penelitian dilakukan terhadap taraf sinkronisasi secara vertikal dan horizontal antar peraturan perundang-undangan yang terkait dengan persaingan usaha.

Data atau informasi dalam penelitian ini berbentuk sumber bahan primer, sekunder dan tersier. Sumber bahan sekunder merupakan tinjauan literatur atas berbagai publikasi. Sumber bahan tersier merupakan bahan yang menjelaskan sumber bahan primer dan sekunder.

Dalam penelitian hukum normatif, penelitian ini menggunakan pendekatan peraturan perundang-undangan, melakukan penelaah terhadap semua undang-undang dan regulasi yang terkait. Pendekatan peraturan perundang-undangan adalah pendekatan dengan menggunakan peraturan dan undang-undang. Dengan metode judisial normatif, penelitian menelaah, mengidentifikasi dan menyesuaikan dengan peraturan perundang-undangan terkait. Penelitian normatif meliputi bahan-bahan hukum primer, bahan-bahan hukum sekunder dan bahan-bahan hukum tersier atau penunjang. Undang Undang Dasar Republik Indonesia Tahun 1945 dan peraturan terkait lainnya sebagai bahan hukum primer. Literatur-literatur berupa jurnal-jurnal hukum, teori-teori hukum, buku ilmiah yang berkaitan dengan judul penelitian, hasil simposium/seminar, dan artikel karangan ilmiah sebagai bahan sekunder. Bahan yang menjelaskan bahan hukum primer dan hukum sekunder sebagai bahan hukum tersier (Johan, S., 2021).

\section{Hasil dan Pembahasan}

\section{Landasan Pengenaan Sanksi Berdasarkan Laporan Keuangan}

Berdasarkan pada PP LPM dan PKPPU, dasar pengenaan denda administatif didasarkan pada laporan keuangan pelaku usaha. Denda dapat dikenakan paling banyak sebesar 50\% (lima puluh persen) dari keuntungan bersih yang diperoleh Pelaku Usaha pada Pasar Bersangkutan, selama kurun waktu terjadinya pelanggaran atau paling banyak sebesar 10\% (sepuluh persen) dari total penjualan pada Pasar Bersangkutan, selama kurun waktu terjadinya pelanggaran. Rumusan pada pengenaan berdasarkan keuntungan bersih dengan pendekatan akuntansi. Pendekatan akuntansi memiliki beberapa kekurangan. Berdasarkan definisi, keuntungan bersih 
merupakan laba kotor setelah dikurangi: biaya tetap yang dibebankan; pajak; dan pungutan negara lainnya.

Akuntansi memiliki pendekatan yang berbeda dengan keuntungan riil. Akuntansi mencerminkan biaya yang telah terjadi maupun yang akan terjadi ke dalam pencatatannya. Akuntasi memasukkan biaya-biaya yang ditangguhkan maupun biaya yang harus dibayar ke dalam perhitungan biaya pada laporan rugi laba. Biaya tetap termasuk biaya depresiasi digolongkan ke dalam biaya ditangguhkan sesuai dengan masa pemakaian alat produksi. Pelaku usaha dapat membebankan biaya-biaya tersebut.

Penggenaan denda berdasarkan laporan keuangan memiliki banyak catatan yang perlu menjadi perhatian. Laporan keuangan memiliki banyak metode pencatattan, sehingga pengenaan denda didasarkan pada penjualan atau keuntungan dan kerugian dapat menimbulkan perhitungan yang berbeda. Selain itu, fungsi verifikasi terhadap laporan keuangan juga akan memiliki efekefek yang berbeda. Laporan keuangan merupakan catatan atas transaksi yang terjadi sedangkan kejadian pelanggaran dapat timbul di masa yang akan datang.

Berdasarkan PPKPU yang memerlukan laporan keuangan teraudit juga menimbulkan ketidakpastian dalam perhitungan denda. Dasar pengenaan denda adalah pasar bersangkutan. Jika sebuah perusahaan beroperaasi di seluruh wilayah di Indonesia. Pasar Bersangkutan hanya pada satu daerah saja, maka laporan keuangan yang dipergunakan tidak mencerminkan kejadian pelanggaran. Sebagai alternatif, laporan keuangan yang didukung oleh keterangan ahli di bidang akuntansi. Hal ini juga menimbulkan polemik, jiak ahli akuntansi hanya melihat catatan yang ada tidak mengenal secara keseluruhan laporan. Seorang akuntan publik mampu melakuan verifikasi laporan keuangan setelah melakukan audit selama beberapa bulan.

Dasar pengenaan denda lainnya adalah berdasarkan nilai penjualan. Sesuai dengan PKPPU, penjualan ditetapkan berdasarkan nilai penjualan sebelum pengenaan pajak atau pungutan negara yang berkaitan langsung dengan penjualan barang atau jasa pada Pasar Bersangkutan. Penjualan sebagaimana dimaksud pada ayat (1) dihitung berdasarkan laporan keuangan yang sah dan meyakinkan; laporan rekening koran; volume penjualan; harga pasar; daftar harga; daftar harga penawaran; rekapitulasi dan bukti penjualan dan/atau pembelian; dan/atau data terkait lainnya Penjualan pelaku usaha harus ditegaskan bahwa ini adalah total penjualan tunai maupun penjualan kredit. Penjualan harus jelas adalah penjualan yang memiliki implikasi pada Pasar Bersangkutan. Penjualan dapat dilakukan oleh perusahaan manufaktur kepada distributor. Distributor menjual kepada konsumen. Penjualan pada peraturan ini tidak dijelaskan penjualan yang mana.

Laporan keuangan juga menimbulkan ketidakpastian dalam penentuan denda sebagaimana dijelaskan di atas. Pelaku usaha tidak selalu menyiapkan laporan keuangan berdasarkan definisi Pasar Bersangkutan. Definisi pasar bersangkutan tidak sama dengan definisi pasar pada laporan keuangan pelaku usaha.

Selain laporan keuangan, jangka waktu pelanggaran yang dapat berbeda dengan masa laporan keuangan akuntansi. Laporan keuangan akuntansi berdasarkan tahun pembukuan yakni tanggal 1 Januari hingga 31 Desember. Jika pelanggaran terjadi pada 1 Maret hingga 30 September, maka laporan keuangan tidak dapat dipergunakan menjadi dasar pengenaan denda.

\section{Pengenaan Sanksi Berdasarkan Laporan Keuangan Dapat Dikenakan Pada Semua Pelanggaran Larangan Praktik Monopoli}

Pelanggaran terhadap larangan praktik monopoli dapat digolongkan menjadi 2 kelompok. Dua kelompok pelanggaran yakni mengajak pelaku usaha lain untuk bersama-sama melakukan pelanggaran atau pelaku usaha tersebut melakukan tindakan korporasi seperti penggabungan, peleburan atau pengambilalihan badan usaha. Dengan penggabungan, peleburan atau pengambilalihan badan usaha, maka pelaku usaha memiliki kemampuan menciptakan pasar dominan. Pengelompokkan pelanggaran ini dijelaskan pada Gambar 2. 


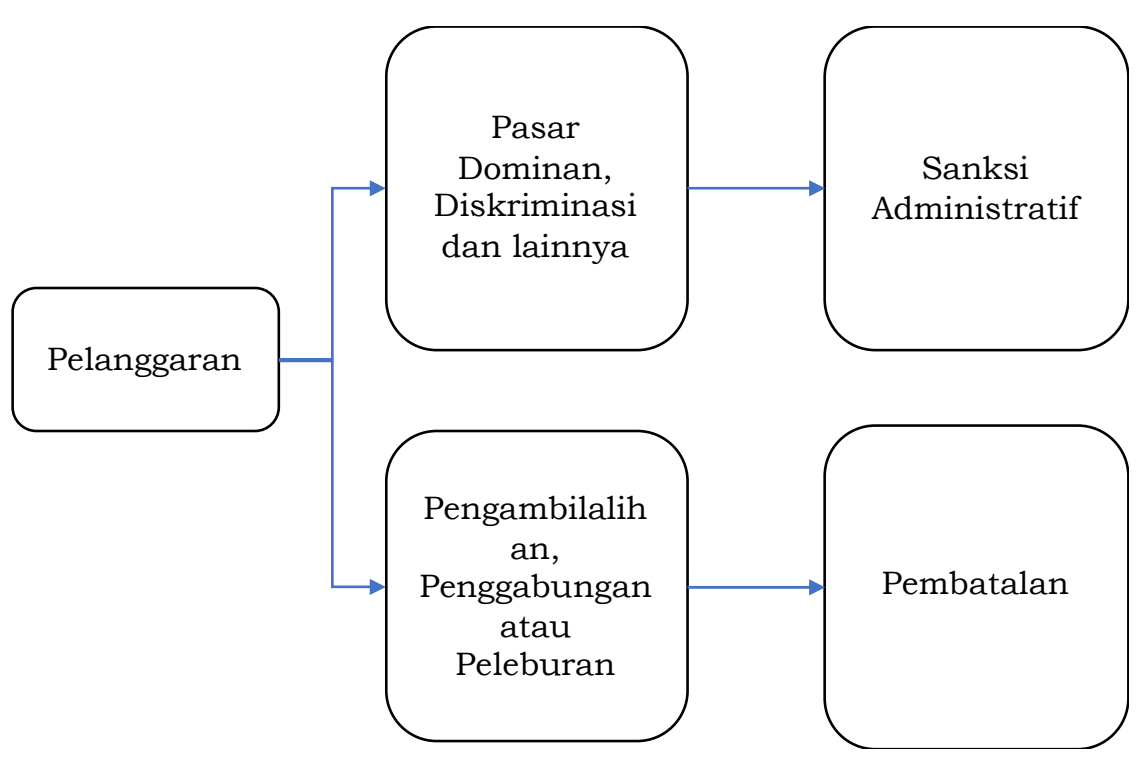

Gambar 2. Jenis Pelanggaran

Sumber: hasil penelitian

Pengenaan sanksi dapat dilakukan pada kelompok pertama. Para pelaku usaha dapat dikenakan denda administratif atas keuntungan yang diperoleh. Berdasarkan Pasal 11 PP LPM, tindakan yang dapat dikenakan pada pelanggaran pasal 28 UU LPM adalah pembatalan transaksi. Dengan demikian, berdasarkan UU CK dan PP LPM, maka transaksi penggabungan, peleburan atau pengambilalihan dapat dibatalkan jika menimbulkan pelanggaran.

Pembatalan ini akan menimbulkan ketidakpastian hukum. Transaksi yang telah terjadi dan dilaporkan kepada KPPU. Setelah KPPU menyelidiki, maka KPPU tidak menyetujuinya. Dengan demikian, transaksi ini harus dibatalkan.

Dengan pembatalan transaksi ini, maka pelaku usaha akan dikenakan biaya tambahan (opportunity cost) selama masa tunggu. Sebaiknya KPPU mengubah pola pelaporan dari post notification menjadi pre notification. Sehingga transaksi ini tidak mudah dibatalkan dan memberikan kepastian kepada para pihak yang melakukan transaksi.

\section{Sanksi Denda Dapat Menurunkan Praktik Monopoli dan Persaingan Usaha Tidak Sehat}

Penggenaan sanksi sebesar paling banyak 50\% dari keuntungan bersih menimbulkan interpretasi bahwa pelaku usaha tetap memperoleh keuntungan $50 \%$ dari pelanggaran yang dilakukannya pada pasar bersangkutan. Dengan batasan paling banyak 50\% dari keuntungan bersih, maka pelaku usaha dapat memperoleh keuntungan yang jauh lebih besar.

Pengenaan paling banyak $10 \%$ dari total penjualan juga menimbulkan pertanyaan, berapakah keuntungan atau margin daripada pelaku usaha atas pelanggaran ini. Pelaku usaha yang melakukan pelanggaran memperoleh keuntungan lebih besar daripada 10\%, maka pelaku usaha tetp memperoleh keuntungan. Dengan pengenaan paling banyak $10 \%$, maka dapat dkenakan di bawah 10\%, maka keuntungan pelaku usaha tetap besar. Pembagian denda ini digambarkan pada Gambar 3.

Dengan kedua pengaturan ini, apakah pelaku usaha membagi keuntungan atau dikenakan denda oleh peraturan yang ada. Denda semestinya diluar daripada keuntungan yang diperoleh oleh pelaku usaha. Pelaku usaha harus mengembalikan semua keuntungan diperoleh ditambahkan dengan denda. Dasar pengenaan denda administratif adalah membagi keuntungan dengan pelaku usaha, bukan denda tambahan. 


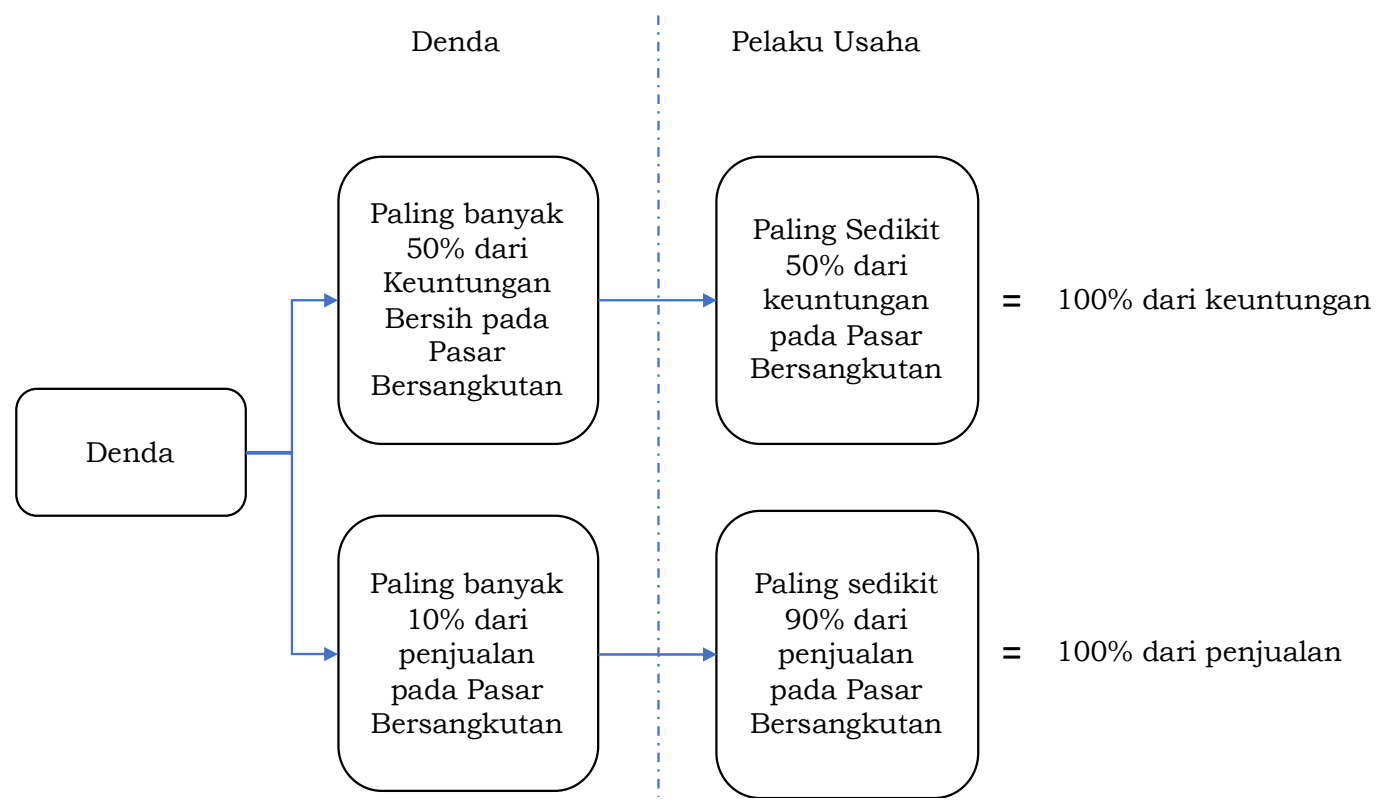

Gambar 3. Pembagian Denda

Sumber: hasil penelitian

Dengan pengenaan denda dengan pedekatan akuntansi ini, pelaku usaha akan dapat tetap melakukannya. Keuntungan yang diperoleh setelah dikurangi denda, mungkin sama dengan keuntungan tanpa pelanggaran atau sebelumnya adanya pelanggaran. Pelaku usaha tidak rugi dengan pelanggaran ini.

Penggenaan denda yang lebih besar dan tepat sasaran akan dapat menurunkan praktek tidak sehat dalam persaingan usaha. Regulator perlu meninjau kembali landasarn pengenaan denda. Peraturan sepatutnya mengenakan denda di atas keuntungan yang diperoleh oleh pelaku usaha. Keuntungan yang diperoleh sepatutnya diambilalih oleh negara atau dikembalikan kepada masyarakat atau konsumen luas. Denda seharusnya membuat pelaku usaha tidak berani melakukannya lagi atau pelaku usaha lain tidak melakukannya di kemudian hari.

\section{Simpulan dan Saran}

KPPU memiliki wewenang dalam memberikan sanksi kepada pelaku usaha yang melanggar Larangan Praktik Monopoli berdasarkan Pasal 47-49 Undang Undang Nomor 5 Tahun 1999. Berdasarkan UU CK, KPPU memberikan sanksi administratif. Sanksi administratif atau denda berdasarkan laporan keuangan akuntansi akan menimbulkan beberapa hal yang tidak jelas bagi pelaku usaha dan memiliki hambatan teknis dalam pelaksanaan. Laporan keuangan secara akuntansi memiliki perbedaan pendekatan dengan kegiatan bisnis yang riil. Sehingga pemberian denda administratif tidak efektif untuk mengurangi pelanggaran.

Pengenaan sanksi pelanggaran Larangan Praktik Monopoli tidak berlaku untuk semua pelanggaran. Pelanggaran dengan melakukan peleburan, penggabunggan dan pengambilalihan tidak termasuk dalam denda administratif. Denda yang dikenakan diberikan berdasarkan total keuntungan yang diperoleh. Denda sepatutnya dikenakan diatas keuntungan yang diperoleh oleh pelaku usaha. Denda atau sanksi administratif yang dikenakan berdasarkan keuntungan bersih pada pelanggaran di Pasar Bersangkutan. Dengan demikian, pelaku usaha tetap memperoleh keuntungan atas pelanggaran yang telah dilakukannya. Masyarakat atau konsumen secara luas tetap dirugikan. Pemberian denda administratif tidak dapat dikenakan pada semua jenis pelanggaran. 
Pemberian sanksi administratif harus mempertimbangkan keuntungan yang telah diperoleh oleh pelaku usaha atas pelanggaran yang terjadi. Perhitungan keuntungan ini berdasarkan estimasi keuntungan. Selain itu pengenaan denda juga dapat didasarkan pada besarya nilai transaksi yang terjadi. Jika denda administrartif terlalu kecil, maka pelaku usaha tetap akan memperoleh keuntungan. Denda harus mampu memberikan efek jera kepada pelaku usaha yang melanggar. Perhitungan denda berdasarkan peraturan perundang-undangan saat ini tidak memberikan efek jera.

Penelitian ini masih berdasarkan peraturan yang baru diterbitkan. Penelitian selanjutnya dapat dilakukan berdasarkan pelaksanaan pelanggaran yang terjadi setelah berlakunya peraturan PP LPM yang baru. Kajian dapat dilakukan berdasarkan keputusan sanksi KPPU terhadap pelanggaran yang telah terjadi dengan dasar perhitungan laporan keuangan.

Penelitian lainnya dapat dikembangkan dengan melakukan studi perbandingan hukum di negara lain. Perbandingan hukum ini akan mampu memberikan contoh sanksi terhadap pelanggaran praktik monopoli. Kajian terhadap efektivitas pelaksanaan peraturan menjadi salah satu kajian yang dapat dilakukan di masa yang akan datang.

\section{DAFTAR PUSTAKA}

Abidin, I. K. R. (2021). Upaya KPPU Menangani Dugaan Pelanggaran Layanan Rapid Test $\begin{array}{llll}\text { Diagnosis } & \text { Covid-19. Jurist-Diction, } & 4(3), & \end{array}$ https://doi.org/https://doi.org/10.20473/jd.v4i3.26981

Arih, S. (2020). Penjatuhan Sanksi Pidana Terhadap Korporasi Pelanggaran Pasal 17 UU No. 5 Tahun 1999 (Studi Kasus Putusan KPPU No.:09/KPPU-L/2016). Focus Hukum UPMI, 1(2), 64-73.

Bimo, E. S. (2021). Dianggap Langgar Aturan Persaingan Usaha Pemerintah China Denda Alibaba 2,8 Milliar Dollar AS. https://www.kompas.tv/article/163176/dianggap-langgaraturan-persaingan-usaha-pemerintah-china-denda-alibaba-2-8-miliar-dollar-as

Chusna, F. A. (2021). Lex Minus Quam Perfecta Pembatalan Merger Oleh KPPU Pasal 47 Undang-Undang Nomor 5 Tahun 1999. Jurist-Diction, 4(2), 635. https://doi.org/https://doi.org/10.20473/jd.v4i2.25782

Deny, S. (2021). KPPU Denda Gojek Rp. 3,3 Milliar. Liputan 6. https://www.liputan6.com/bisnis/read/4515645/kppu-denda-gojek-rp-33-miliar

Farras, B. (2018). Terbukti Monopoli, Grab \& Uber Kena Denda Rp.141,6 Milliar. Cnbcindonesia. https://www.cnbcindonesia.com/tech/20180924112709-37-34436/terbuktimonopoli-grab-uber-kena-denda-rp-1416-m

Jelita, I. N. (2021). KPPU Denda Garuda Rp. 1 M terkait tiket Umrah. https://mediaindonesia.com/ekonomi/417378/kppu-denda-garuda-rp1-m-terkait-tiket-umrah

Johan, S., \& A. A. (2021). Keterbukaan Informasi Uu Pasar Modal Menciptakan Asymmetric Information Dan Semi Strong Form. Masalah-Masalah Hukum, 50(1), 106-118. https://doi.org/https://doi.org/10.14710/mmh.50.1.2021.106-118

Johan, S. (2011). Implementasi Strategi Bisnis dan Korporasi Melalui Merger dan Akuisisi. ULTIMA Management, $\quad 3(1), \quad 68-81$. https://doi.org/https://doi.org/10.31937/manajemen.v3i1.176

Johan, S. (2020). Implikasi Yuridis Post Merger Notificatin Oleh Pelaku Usaha Di Indonesia. Dialogia Iuridica: Jurnal Hukum Bisnis Dan Investasi, 12(1), 64-80. 
https://doi.org/https://doi.org/10.1007/s11747-013-0336-7

Johan, S. . et. a. (2012). Key Financials Performance Independent versus Integrated: Empirical Evidence from Indonesia Financial Service Industry (2001-2011). International Journal of Economics and Finance, 5(1). https://doi.org/https://doi.org/10.5539/ijef.v5n1p92

Kasenda, Q. E., Pangkerego, O. A., \& Sarapun, R. M. S. (2021). Sanksi Hukum Terhadap Pelaku Praktik Monopoli Dan Persaingan Usaha Tidak Sehat Berdasarkan Undang Undang Nomor 5 Tahun 1999. Lex Administratum, 9(6), 178-187.

Made, G. (2021). Kewenangan KPPU Menjatuhkan Sanksi Daftar Hitam dalam Penegakan Hukum Persaingan Usaha. JISIP (Jurnal Ilmu Sosial Dan Pendidikan), 5(2). http://ejournal.mandalanursa.org/index.php/JISIP/article/view/1823

Nazhifah, N. A., Yumarni, A., \& Gilalo, J. J. (2019). Study of Decision of The Supreme Court Number 310 K/PDT.SUS-KPPU/2017 Concerning Delay in Notification of Takeover of Foreign Company Shares. Jurnal Hukum De'rechsstaat, 5(2), 93-104.

Paparang, J. A. (2019). Tugas dan Wewenang KPPU Dalam Penanganan Pelanggaran Hukum Persaingan Usaha Menurut Undang Undang Nomor 5 Tahun 1999. Lex Privatum, 7(7), 3241.

Pradhana, W. A., \& P. (2020). Akibat Hukum Bagi Konsorsium Yang Diputus Bersalah Dalam Perkara Komisi Pengawas Persaingan Usaha (Kppu). Jurnal Privat Law, 8(1), 158. https://doi.org/https://doi.org/10.20961/privat.v8i1.40390

Rosan, F. C. (2021). Denda Maksimal Pelanggar Persaingan Usaha Dihapus di Omnibus Law Ini Kata KPPU. Tempo. https://bisnis.tempo.co/read/1402326/denda-maksimal-pelanggarpersaingan-usaha-dihapus-di-omnibus-law-ini-kata-kppu

Rumatiga, H. (2021). Unfair Business Competition In Comestibles Trade Related To Law No. 5 of 1999 Concerning Prohibition of Monopoly and Persault Practices. Living Law, 13(5), 3545.

Sandi, F. (2021). Terbukti Langgar Persaingan Bisnis, Lion Kena Denda KPPU. https:/www.cnbcindonesia.com/news/20210329152936-4-233685/terbukti-langgarpersaingan-bisnis-lion-air-kena-denda-kppu

Sukarmi. (2021). Putusan Kppu Sebagai Dasar Dalam Gugatan Kelompok (Class Action) Atas Pengembalian Kerugian Konsumen Akibat Pelanggaran Persaingan Usaha Tidak Sehat. Arena Hukum, 14(1), 112-129. https://doi.org/https://doi.org/10.21776/ub.arenahukum.2021.01401.6

Susanto, V. Y. (2021). Telat Notifikasi akusisi, KPPU denda Saratoga Investama (SRTG) Rp. 1 Milliar. 